November 2007

\title{
The UK Government and the 1994 Genocide in Rwanda
}

Linda Melvern

Follow this and additional works at: https://digitalcommons.usf.edu/gsp

\section{Recommended Citation}

Melvern, Linda (2007) "The UK Government and the 1994 Genocide in Rwanda," Genocide Studies and Prevention: An International Journal: Vol. 2: Iss. 3: Article 5.

Available at: https://digitalcommons.usf.edu/gsp/vol2/iss3/5

This Articles is brought to you for free and open access by the Open Access Journals at Digital Commons @ University of South Florida. It has been accepted for inclusion in Genocide Studies and Prevention: An International Journal by an authorized editor of Digital Commons @ University of South Florida. For more information, please contact digitalcommons@usf.edu. 


\title{
The UK Government and the 1994 Genocide in Rwanda
}

\author{
Linda Melvern
}

"I can think of no more irresponsible act of a British government in modern times..." -Geoffrey Robertson, $\mathrm{QC}^{1}$

The genocide that took place in Rwanda in 1994 will remain, for our generation, the enduring failure to intervene in the face of massive human-rights abuse. The genocide lasted for three months, and during that time an estimated one million people were killed. The killing was organized in advance; it was the direct result of a deliberate government policy and was carried out according to an explicit strategy.

The combination of revelations about the scale and the intensity of the genocide, the failure to intervene to prevent it or to stop its progression country-wide, and the suppression of information about what was actually happening is a shocking indictment not just of the UN Security Council but of governments and individuals who knew what was happening and who chose to remain silent. The failure of UN policy toward Rwanda, a policy devised by members of the Security Council, had a decisive effect on events. It merits precise documentation.

The focus of this article is the role of the British government led by Prime Minister John Major. While the United Nations has shown its willingness to uncover how and why it reacted the way it $\mathrm{did}^{2}{ }^{2}$ in the United Kingdom there continues to be a reluctance to try to account for Britain's policies toward Rwanda. Neither press nor Parliament has shown any enthusiasm to scrutinize this particular part of history or to explain why the United Kingdom, a country with a permanent seat on the UN Security Council, should have chosen to influence events in the way it did. ${ }^{3}$ Britain, far from taking a back seat, was instrumental in shaping the UN response to the crisis, ${ }^{4}$ and this leaves unanswered a central question: Was the United Kingdom, a country with special power and privilege in the Security Council, impotent or unwilling to implement the 1948 UN Convention on the Prevention and Punishment of the Crime of Genocide (UNCG), ${ }^{5}$ either to prevent the occurrence of genocide in Rwanda or, once it began, to stop it from spreading?

In the United Kingdom, a country where secrecy pervades most aspects of government, the issue of Rwanda is particularly sensitive. There are continuing attempts to obscure individual responsibility in the decision-making process. There is even a claim that, in the archives of the Foreign and Commonwealth Office (FCO) in Whitehall, the paper trail on Rwanda, 1990-1994, has been weeded. ${ }^{6}$ There is resistance to release any of the diplomatic cables that passed between the policy makers in London and Britain's UN mission in New York. Some officials involved at the time are reluctant even to discuss Rwanda, a reluctance bolstered by the ongoing failure of press and Parliament to examine this episode in British foreign policy. In the writings and memoirs of those concerned, there is hardly a relevant word-in John Major's case, the genocide has completely vanished from the public version of his period in office. ${ }^{7}$

Linda Melvern, "The UK Government and the 1994 Genocide in Rwanda," Genocide Studies and Prevention 2, 3 (November 2007): 249-258. (C) 2007 Genocide Studies and Prevention. doi: $10.3138 / g s .2 .3 .249$ 
When I first began to query government policy toward Rwanda, I was given various reasons for the inaction. I was told that the FCO and the then foreign secretary, Douglas Hurd, did not know what was happening in Rwanda. "We had absolutely no sources of information," our UN ambassador, David Hannay, told me. "The genocide came like a bolt from the blue," another insider claimed. There was no British embassy in Rwanda, which was considered to be in the "francophone sphere" of Africa; the government had simply believed what the French were saying. ${ }^{9}$ Alternatively, it was claimed that British policy makers were given inadequate briefings by UN officials in the Security Council and that this had made the United Kingdom "look in the wrong direction." There were several claims that the United Kingdom had simply gone along with "UN policy."

It remains unclear what advice, if any, the FCO's legal advisors, headed by Sir Franklin Berman, offered on the determination of genocide in Rwanda and the responsibility of the British government, as a signatory to the 1948 UNCG, to abide by this treaty. By contrast, in the United States, under the Freedom of Information Act, some relevant memoranda from the Office of the Legal Advisor have been released. ${ }^{10}$ But the rest of the story is hidden from view, and requests in the United States for a congressional investigation into the decision-making process are ignored. Only a tiny fraction of the government documents regarding this issue has been released.

\section{Peacekeeping in Rwanda}

With hindsight, the creation by the UN Security Council of a feeble UN peacekeeping mission for Rwanda-with its weak mandate and minimal capacity, suitable for only the most benign environment-is seen to have been a tragic error. On the face of it, the UN assignment in Rwanda was unambiguous, with a three-year civil war that had ended in peace and a handshake between government and invading rebels. The corrupt regime was to be reformed and a power-sharing government created. This was classic, textbook peacekeeping; there would be no proactive soldiering, no peace enforcement. Peacekeepers monitor compliance with cease-fires; they do not seize weapons. The peacekeepers of the UN observe, they mediate, but they do not compel the parties to cease hostilities, nor do they try to end human-rights abuses.

In peacekeeping, the transition period, when the warring factions vie for power, is the most dangerous. It is the time used by extremists to make the most of the vacuum, to derail peace. In the case of Rwanda, by the time the UN peacekeepers arrived, it was probably already too late. And just how half-hearted this UN mission was is plain to see, for it lacked even the barest essentials. It was soon clear that the readiness level of this paltry force bore no relationship at all to what was needed.

The timing for Rwanda and its fragile peace agreement could not have been worse. The UN Assistance Mission for Rwanda (UNAMIR) was created as a small and rather insignificant mission at a time when the Security Council was preoccupied elsewhere. There was a crowded agenda and new demands on the council's time; the end of the Cold War had led to an evolution in peacekeeping, with a series of new high-cost, large-scale, and open-ended missions created in the early 1990s. The Security Council had enacted a blizzard of peacekeeping mandates, and some of them had proved ambiguous, inadequate, and written with scant consideration for the realities on the ground. In the former Yugoslavia there had been tragic mistakes, particularly when the Security Council sent peacekeepers into situations with orders they 
could not follow. When UNAMIR was created, the council was responsible for seventeen UN missions worldwide and some 80,000 peacekeepers in the field. It was trying to keep track of problematic operations in Cambodia, in Somalia, and in the former Yugoslavia. Rwanda seemed quiet. In comparison with other missions it seemed even hopeful, and there existed a degree of optimism about the Arusha peace accords.

Peacekeeping requires ceaseless political direction. In every operation throughout the world, the mandate, authorized by the Security Council, provides crucial guidance. By the end of February 1994, the mission for Rwanda was beginning to cause concern, and at the end of February there was a series of violent incidents, with militia seizing the center of Kigali and a series of political murders. These events were of such concern that the Belgian foreign minister, Willy Claes, flew to Kigali, and almost immediately upon his return home Belgium decided to ask the Security Council for a more robust mandate for the peacekeepers. The Belgian government, which had 450 paratroopers in UNAMIR and intelligence operatives attached to its embassy in Rwanda, warned that the mission was in the deepest trouble. It asserted that the peacekeeping mandate must be increased to allow for a more robust UN response in the face of increasing violence. ${ }^{11}$ In New York, urgent meetings were convened by Belgium's ambassador to the United Nations, Paul Noterdaeme. There was a diplomatic blizzard from Belgian diplomats who believed that the peace agreement in Rwanda was being sabotaged and that if this UN mission collapsed the result would be a huge loss of life. The peacekeepers needed to be able to take proactive action and to seize illegal and stockpiled weaponry; they needed better protection and reinforcements. After the genocide, an enquiry by the Belgian Senate would reveal how two members of the Security Council, the United Kingdom and the United States, given these warnings, remained adamant that no further help should be given to Rwanda. These two states were showing reluctance about the mission. In fact, given the level of violence, they wanted a time limit imposed, for it seemed unwise for peacekeepers to remain in a country where the peace agreement was collapsing. Unless the situation improved and the peace agreement got back on track, the UN peacekeepers would have to pull out completely.

This idea, which was discussed at an informal Security Council meeting on 5 April 1994, did not receive unanimous support. Ibrahim Gambari, the representative for Nigeria, a non-permanent member of the council, argued that Rwanda-one of the poorest countries in the world-should be given sufficient time to achieve democracy. Rwanda should receive the same resources and attention given by the council to other conflict zones, particularly in the former Yugoslavia, where the Council had mandated more peacekeepers than anywhere else in the world.

By now the British government was in possession of its own information about Rwanda. A report detailing the very real risks involved had been sent to London, written by Edward Clay, High Commissioner in Kampala, Uganda, who-after a visit to the Rwandan capital, Kigali-provided the FCO with details of what was happening. ${ }^{12}$ One insider would later claim that had this report received the attention it deserved, Britain's record in the Security Council at this time would have been somewhat different.

It has since been acknowledged that the British government was also reading detailed cables about Rwanda from UNAMIR Force Commander Roméo Dallaire with desperate warnings of impending calamity ${ }^{13}$ It remains unclear how the British government managed to obtain strictly internal UN documents. 
Also available to the British government was more public information from human-rights groups, giving extensive detail about Rwanda: the formation and training of a country-wide militia, the existence of death squads committing political murder, and continuing arms purchases in contravention of the peace accord. There was evidence of a racist propaganda campaign against the Tutsi minority in extremist publications and over the airwaves of the newly created Radio-Télévision Libre des Mille Collines (RTLM), which was relentless in its incitement to ethnic hatred. The UN Commission on Human Rights had sent a special rapporteur, Bacre Waly Ndiaye, to Rwanda; he thought the word "genocide" was appropriate to describe the killing by the government of members of the Tutsi group. Ndiaye warned of "the odious disinformation advocating ethnic and political intolerance, hatred and violence."14

British journalist Richard Dowden, foreign editor of the Independent, was told during a January 1994 visit to Rwanda that militia were being armed by the government and that there were plans to promote mass killings of Tutsis throughout the country. The warning came from Philippe Gaillard, chief delegate of the International Committee of the Red Cross (ICRC). Gaillard warned that genocide could take place. But Dowden later wrote that Gaillard was the only person who spoke to him of genocide and that everyone else he had spoken to had been optimistic. To write a "sensational story about impending genocide would have been dishonest and irresponsible," he thought. ${ }^{15}$

Among others who saw the warning signs was a Polish peacekeeper, Major Stefan Stec, who described how, in the weeks beforehand, "genocide hung in the air." The peacekeepers had opened reception centres for Tutsi families, who were frequently trapped in their homes by Hutu Power militia and too scared to sleep at home. ${ }^{16}$ Some of Kigali's churches were also used in this way. Some Rwandans chose exile. Others believed that with the United Nations in their country they would be safe.

In all these circumstances, the British government may not have been as ignorant as it professed to be.

\section{Warning Signs in Kigali}

In one telling paragraph in the 2005 Report of the Commission for Africa are these words: "Just 5,500 troops with robust peace enforcement capabilities could have saved half a million lives in Rwanda. Evidence shows that prevention can work."17

This, then, is most likely the first indication of an admission by British government signatories of grievous errors made by politicians and civil servants on Britain's behalf in 1994.

The question of when exactly the government was aware that genocide was underway is crucial. Some sources have confirmed that within weeks genocide was apparent; the information came from the most reputable sources, including the ICRC and the British agency Oxfam.

One now retired senior civil servant recalls that immediately before the genocide the Foreign Office warned the Cabinet Office that there could be great loss of life in Rwanda. There appears to have been an assumption that should the peace agreement collapse, there would be many casualties, and that massacres would take place similar to those that had taken place in neighbouring Burundi in October 1993, when an estimated 50,000 people had been killed. In relation to Rwanda in late 
April 1994, another insider comments, "When it got to 100,000 dead we thought it was a bit persistent."

In the United Kingdom, it was Oxfam that first publicly acknowledged the genocide in a press release dated 29 April: "Oxfam fears genocide is happening in Rwanda." At this stage, the British government chose to obscure the reality, describing what was happening only as "civil war." In the Security Council in New York it was the British ambassador, David Hannay, who first offered the idea that the UN peacekeepers be withdrawn; he suggested leaving behind in Rwanda a "token force to appease public opinion." Hannay said that the peacekeepers could achieve very little and that ambassadors should beware a repetition of Somalia, where a few months earlier a peacekeeping mission had spiraled out of control, ending in ignominious failure, at least for the US military. Peacekeeping was not appropriate in the midst of civil war, Hannay said. ${ }^{18}$

But the situation in Rwanda was strikingly different from that which had existed in Somalia a few months before. In Rwanda a civil war was under way, but so was genocide-and at a terrible speed, in broad daylight, in schools, hospitals, clinics, and churches, the places where terrified Rwandan citizens had sought refuge. The eventual Security Council decision, made public on 21 April, to withdraw the bulk of the UN mission may have encouraged the génocidaires, for within a few hours of this vote in New York the killing in Rwanda spread south.

In the days that followed, three non-permanent members of the Security Councilthe Czech Republic, New Zealand, and Nigeria-made every effort to try to persuade both the United Kingdom and the United States to focus their attention not just on the civil war but on the daily murder of thousands upon thousands of civilians. These three states tried to persuade the great powers that the council should recognize that genocide was underway. Were the genocide to be recognized, they argued, there would be a legal and a moral imperative to do something about it. These countries also lobbied for reinforcements for UNAMIR. But the resistance was determined, and at the end of April there was an eight-hour debate in the Security Council about the use of the word "genocide" in relation to Rwanda. During this debate, the United Kingdom argued strenuously against the use of the word. In the end, the council reached a compromise. It was thanks only to the drafting ability of the British that the Presidential Statement issued by the council used wording from the 1948 UNCG but avoided using the word itself. The statement read in part,

The Security Council recalls that the killing of members of an ethnic group with the intention of destroying such a group in whole or in part constitutes a crime punishable under international law. ${ }^{19}$

That same day in Geneva, the headquarters of the ICRC, whose delegates were operating an emergency hospital in Kigali, issued the most strongly worded statement in that organization's history. It described how whole families were being exterminated, and, in a clear message to the Security Council, the ICRC demanded that measures be taken to put an end immediately to what it called the "terrifying mechanism of the massacres." ${ }^{20}$ By now evidence of mass slaughter was leaking through Rwandan rivers: an estimated 40,000 bodies were removed from Lake Victoria. Oxfam, in spite of a lack of interest from the British press, kept up the pressure, and on 3 May a letter was sent to Prime Minister Major informing him that genocide was happening in Rwanda. But the British government continued to want to deny the reality. On 9 May, the House of Commons was told by Mark Lennox-Boyd, the parliamentary under-secretary of state for foreign and 
commonwealth affairs: "There are estimates that more than 200,000 may have perished in recent fighting in Rwanda ... it is a horrific and tragic civil war."21 Yet by that time the latest ICRC estimate was that 250,000 people had been murdered-not killed in a civil war.

That murder of this magnitude could unfold without the government of the day's making any statement on the issue of genocide to Parliament is extraordinary. It was not until six weeks after the genocide began that there was a debate in Parliament, and only because one Opposition member managed to get the issue on to the agenda. On 24 May, Labour MP Tony Worthington expressed shock that so little attention had been paid to Rwanda. Worthington told an almost empty House of Commons at close to midnight, "It is inconceivable that an atrocity in which half a million white people had died would not have been extensively debated in the House." Worthington said that the press had a terrible tendency to dismiss the events as tribalism. "Genocide is certainly involved," he continued. ${ }^{22}$ There had never been a clearer example of genocide, and he warned the House of Commons that Britain was a signatory to the 1948 UNCG. He was told that Rwanda was in the "midst of civil war" and that the UK "was at the forefront of those insisting the UN should remain engaged." 23

This was not quite the case. In the Security Council, as we have seen, it was the Czech Republic, New Zealand, and Nigeria, three non-permanent members, that were insisting that the UN remain engaged in Rwanda. A month later, Worthington made another plea for information about Rwanda: "What kind of House and Government do not seek to make a statement when 500,000 are murdered?" Worthington asked on 22 June. "We are on the Security Council," he reminded the House of Commons. ${ }^{24}$

That genocide in Rwanda had occurred was officially recognized by an impartial commission of experts, created by the Security Council in July 1994, whose interim report to the council in October 1994 documented that "a concerted, planned, systematic and methodical" campaign against the Tutsi and Hutu opponents of the extremists had taken place. There were ample grounds to prove that the 1948 UNCG had been violated between 6 April and 5 July 1994. ${ }^{25}$ A provisional list of massacre sites was produced. Corpses were still piled high in classrooms and churches, strewn across the country in an apocalyptic landscape.

As previously noted, the world's catastrophic failure in Rwanda has been examined by the United Nations through an independent inquiry seeking to establish the role of that organization in what happened. The Carlsson Report into the actions of the United Nations during the genocide in Rwanda was authorized by Kofi Annan, who became secretary-general in December 1996 after the United States vetoed a second term for Boutros Boutros-Ghali.

This report, published in December 1999, calls the genocide "one of the most abhorrent events of the twentieth century." 26 The report leaves no doubt that each part of the UN system, and in particular the secretary-general, the Secretariat, the Security Council, and the member states, must assume and acknowledge their responsibility in the failure.

To this day the British government has not done so.

For three months of genocide, from the beginning to the end, all UN governments and official bodies continued to recognize as legitimate the government of Rwanda, a government hastily sworn into office as the genocide began and intended to replace those government members, part of Rwanda's pro-democracy movement, who had 
just been murdered. It was called an interim government, and for the next three months it would create a regime based on genocide. This government was represented on the UN Security Council; for the duration of the genocide it ran a spin campaign to convince the world that people were dying in the renewed civil war. Not one government called on the génocidaires to stop the genocide. Not one government called for Rwanda's representative to be suspended from the Security Council.

The British government was reluctant to take even the slightest action-such as jamming the hate radio. The government paid no attention to either stabilizing or reinforcing the tiny garrison of UN peacekeepers that had stayed behind in Rwanda. At first Lt-Gen Dallaire, following the loss of ten Belgian peacekeepers in the first hours of the crisis, was told to plan for total evacuation of the force, but he refused and stayed on in Rwanda with volunteers. His was the "token force" that Hannay mentioned. These soldiers, mostly from Ghana and Tunisia, had been mandated by the Security Council to try to negotiate a cease-fire in the civil war. Beyond this mandate, Dallaire and his men were also trying to save as many people as possible, sometimes risking their own lives to do so. In daily contact with Dallaire were officials in the UN's Department of Peacekeeping Operations in New York, headed by Kofi Annan, who were making desperate efforts on Dallaire's behalf to get him rations, gasoline, water-anything at all. But Dallaire and his men were not even resupplied. In one cable to headquarters he wrote,

The ineffective reaction to meeting the critical needs of this mission is nothing less than scandalous from the word go and even bordering on the irresponsible.... This has directly led to the loss of many more Rwandan lives, to the casualties among our troops. $^{27}$

Reinforcements were available for Rwanda. A Ghanaian company of soldiers was on stand-by in Nairobi, and other African countries also offered troops. ${ }^{28}$ What was urgently needed was an airlift to get them to Rwanda and about thirty armored personnel carriers to help protect troops on the ground. In response to these urgent requests from UN officials, the British Ministry of Defence and its then minister, Malcolm Rifkind, offered fifty four-tonne four-wheel-drive trucks-but no means to get them to Rwanda. Still, the offer allowed the Major government to claim, on 13 July, that the United Kingdom had "responded to the request of the Secretary-General for the supply of equipment." 29 It was yet another tactic used by the UK government to deflect the reality of the situation. A variety of British government representatives would subsequently claim that the United Kingdom was doing all that the UN had asked of it. It was for the want of fuel, not courage, that more Rwandans were not rescued.

In June 1994 Dallaire flew to Nairobi, where, at a press conference, he told international journalists they had dropped the ball: they were allowing "fence-sitting politicians off the hook for the Rwandan genocide." ${ }^{0}$ But with no outcry about genocide in the press, no choices were given and no risks taken. The genocide, described in British newspapers with inappropriate and racist clichés such as "tribal bloodletting," gave the impression that what was happening was too terrible for "foreigners" to prevent; this bolstered the line from the UK diplomats and politicians who kept insisting that only a massive and dramatic intervention would succeed and that such an intervention was out of the question in the midst of a civil war.

Rwanda's genocide occurred in the year in which we wept through Steven Spielberg's Schindler's List; it was happening while Western leaders walked along 
the D-Day beaches and celebrated the defeat of fascism. It was left to "UN peacekeepers" to take the blame for Rwanda.

In both London and Washington there are politicians and civil servants who made decisions in 1994 that cost the lives of an incalculable number of people. They should bear full responsibility. The 1948 UNCG was the world's first truly universal, comprehensive, and codified protection of human rights. It stands for a fundamental and important principle: that whatever evil may befall any group, nation, or people, it is a matter of concern not just for those people but for the entire human family.

The United Nations was founded on the commitment to the rule of international law-and to a rules-based international society. The erosion of this law and its abuse by democratic politicians should be of some concern. In an effective democracy, it is the job of journalists to ensure that governments do not evade their responsibility under international law and that they are held accountable for their actions. This story is massively incomplete, as the author is the first to admit. We should never forget the gaps.

In a recent off-the-record interview with a foreign office insider, someone who later became a senior figure in the government of Tony Blair, I asked why the British response had been so poor. This was the shocking and cynical reply: "Of course we didn't do anything... [about Rwanda]... Neither the press nor the public was interested."

\section{Notes}

1. Statement by Geoffrey Robertson, QC, Doughty Street Chambers, London, July 2006.

2. Ingvar Carlsson, Han Sung-Joo, and Rufus M. Kupolati, Report of the Independent Inquiry into the Actions of the United Nations during the 1994 Genocide in Rwanda, UN Doc. S/1999/1257 (1999), http://www.un.org/Docs/journal/asp/ws.asp?m=S/1999/1257 (accessed 1 August 2007) [Carlsson Report].

3. The main exceptions are Linda Melvern, "Death by Diplomacy," The Scotsman, January 1995, 1-3; Linda Melvern, "The UN and Rwanda," London Review of Books 18, no. 24 (1996):11-14; Linda Melvern, "Missing the Story: The Media and the Rwandan Genocide," Contemporary Security Policy 22, no. 3 (2001): 91-106; and Linda Melvern, 'Is Anyone Interested in Rwanda?' British Journalism Review 12, no. 2 (2001): 52-58.

4. University of Wales, Aberystwyth, Hugh Owen Library, Rwandan Genocide Archive, Security Council "Informals," account of meetings, April-May 1994. The same materials are also held in the author's archives.

5. Convention on the Prevention and Punishment of the Crime of Genocide, 9 December 1948, 78 U.N.T.S. 277, http://www.unhchr.ch/html/menu3/b/p_genoci.htm (accessed 1 August 2007).

6. Senior official, Overseas Development Agency (retired), interview with the author, 2005.

7. John Major, John Major: The Autobiography (London: HarperCollins, 1999).

8. Lord David Hannay (former British ambassador to the United Nations), interview with the author, December 1999.

9. Official, Foreign and Commonwealth Office (retired), interview with the author, April 2000.

10. Freedom of Information Project, National Security Archive, Washington, DC, http:// www.nsarchive.org (accessed 20 August 2007).

11. Belgian Senate, Report of the Commission d'Enquête parlementaire concernant les évéements au Rwanda (6 December 1997).

12. Linda Melvern with Paul Williams, "Britannia Waived the Rules: The Major Government and the 1994 Genocide in Rwanda," African Affairs 103 (2004): 1-22.

13. Peter Hain, MP, Aegis Award speech, January 2002. 
14. Bacre Waly Ndiaye, report on Special Rapporteur's mission to Rwanda, 8-17 April 1993, UN Doc. E/CN 4/1994/7/Add. 1 (11 August 1993).

15. Richard Dowden, "Comment: The Rwandan Genocide: How the Press Missed the Story. A Memoir," African Affairs 103 (2004): 283-90, 284.

16. Major Stefan Stec, interview with the author, The Hague, September 1997.

17. Our Common Interest: Report of the Commission for Africa (Commission for Africa, 2005), http://www.commissionforafrica.org/english/report/thereport/cfafullreport_1.pdf (accessed 2 August 2007), 37.

18. These statements are based on an account of Security Council discussions between 1 April and 19 May 1994 given by ambassadors Colin Keating of New Zealand and Karel Kovanda of the Czech Republic in interviews conducted in New York in July 1994. Linda Melvern archive, Hugh Owen Library, University of Wales, Aberystwyth.

19. Statement by the President of the Security Council, UN Doc. S/PRST/1994/21 (30 April 1994), http://daccessdds.un.org/doc/UNDOC/GEN/N94/199/86/PDF/N9419986.pdf (accessed 2 August 2007); see Boutros Boutros-Ghali, ed., The United Nations and Rwanda, 1993-1996 (New York: United Nations, 1996), 271.

20. International Committee of the Red Cross, "Cri d'alarme de CICR au nom des victimes de la tragédie Rwandaise," statement, 28 April 1994, Geneva.

21. Hansard Parliamentary Debates, Commons, 6th ser., vol. 243 (1994), cols. 313-14 (emphasis added).

22. Hansard, Commons, 6th ser., vol. 244 (1994), cols. 308-9.

23. Ibid., cols. 313-14.

24. Hansard, Commons, 6th ser., vol. 245 (1994), col. 304.

25. Interim report of the Commission of Experts established in accordance with Security Council Resolution 935, UN Doc. S/1994/1125 (4 October 1994), http://daccessdds.un.org/ doc/UNDOC/GEN/N94/381/91/PDF/N9438191.pdf (accessed 2 August 2007); Final report of the Commission of Experts established pursuant to Security Council resolution 935, UN Doc. S/1994/1405 (9 December 1994); Carlsson Report.

26. Carlsson Report, 3.

27. Author's archives, outgoing code cable from UNAMIR Force Commander, 12 July 1994.

28. Interviews, UN Secretariat, New York, July 1994.

29. Hansard, Commons, 6th ser., vol. 246 (1994), col. 971.

30. Roméo Dallaire with Brent Beardsley, Shake Hands with the Devil: The Failure of Humanity in Rwanda (Toronto: Random House, 2003), 346. 